\title{
THE HIGH SCHOOLS OF NEW ENGLAND, AS JUDGED BY THE STANDARD OF THE COLLEGE CERTIFI- CATE BOARD
}

WALTER H. YOUNG, A.M.

Principal Lewis High School, Southington, Conn.

Any attempt to secure articulation between the high schools and colleges is worthy of attention. Especially interesting is the attitude of the College Entrance Certificate Board, and the ability of the high schools of New England to satisfy the new demands. For this reason we have undertaken a careful investigation of existing conditions in order to determine how successfully the high schools are meeting the college requirements.

\section{THE CERTIFICATE BOARD}

The New England College Entrance Certificate Board was organized at Boston on May I6, I902. The institutions now holding membership in the board are Amherst, Boston University, Bowdoin, Brown, Dartmouth, Mt. Holyoke, Smith, Tufts, University of Maine, Wellesley, Wesleyan, and Williams. The board originally consisted of nine institutions, but three more were admitted later until now it represents the large per cent. of colleges in New England which admit on certificate.

The high-school principals were soon given official notice that after January I, I904, no certificates would be accepted from any school in New England which had not been approved by the board. Thus all privileges were taken away from the just and the unjust alike, and things started upon a new basis. Among the rules of the board we find:

RULE V. No school shall be approved unless it has shown by the record of its students already admitted to college its ability to give thorough preparation for college; or unless it can satisfactorily meet such tests as the board may establish to determine its efficiency.

RULE VI. The board shall have the power of withdrawing approval from a school, and from such a school certificates shall not afterwards be accepted until it shall have again been approved by the board.

RULE VIII. A general report of the work of pupils from approved schools 
for at least one-third of their first year in college shall be made to the board ... . a and all complaints of insufficient preparations shall be made to the board with specifications as to subjects and individuals. . . . .

While we pass over the query why the New England schools have been so grievously at fault that they should be thus discriminated against, we may congratulate ourselves that we have a standard by which we are able to judge the work of these schools. For, after making allowance for the idiosyncracy of the college professor, and his tendency to ride his special hobby, this standard is for the most part maintained without fear or favor, and constitutes the best available criterion of the preparation of the boys and girls for college work.

\section{THE APPROVED LIST}

How nearly the high schools of New England have been able to measure up to the required standard may be seen from the following table:

TABLE I

\begin{tabular}{l|r|r|r|r|r|c}
\hline \hline & Maine & N. H. & Vt. & Mass. & R. I. & Conn. \\
\hline No. high schools in state............. & I47 & 57 & 64 & 245 & 20 & 77 \\
No. high schools with certificate privilege & 25 & I7 & 9 & I I & II & I5 \\
Per cent. with certificate privilege........ & I7 & 30 & I4 & 46 & 61 & 20 \\
\hline
\end{tabular}

We are at once confronted by the question why so many of the high schools of New England are not on the approved list. The number below standard is appalling; so large, in fact, that one must admit that the high schools as a whole do not satisfy the requirements of the colleges. On the other hand many prominent educators hold that the colleges are too unreasonable in their demands and too unscientific in their methods; that the failures during the first term of the freshman year could be largely avoided by more pedagogical teaching and a logical attempt at correlation.

Up to November I, I905, 502 different schools applied for approval. Of these 220 were approved for three years, 48 were put on the trial list, and 136 were refused approval, 6 had to wait for the action of the board, and 92 had not as yet sent the secretary the required data. The 136 schools not approved were located as follows: 
TABLE II

\begin{tabular}{c|c|c|c|c|c|c}
\hline \hline Maine & N. H. & Vt. & Mass. & R. I. & Conn. & Total \\
\hline 29 & I5 & I0 & $5^{8}$ & 4 & 20 & I36 \\
\hline
\end{tabular}

"Of these 87 are public schools, 27 are academies, and 22 are private schools. One-half, or 68 , were rejected because the records of the pupils sent on certificate during the previous three years to the colleges represented on the board were not satisfactory. Most of the others failed of approval because the number of pupils received within the previous three years had been too small to enable the board to form a satisfactory opinion in regard to their work."

\section{CLASSIFICATION OF HIGH SCHOOLS}

High-school education in New England is individual and sporadic; there is no system. The character of instruction, the standard of attainment, and the general policy of the school, are determined by local sentiment. This, as every educator knows, is an uncertain quantity, often fluctuating, seldom reliable, and quite as often doing more harm than good. And while each of the states has a law providing that every boy or girl may, if prepared, attend an approved high school, and while the tuition, and in some states the transportation also, is paid by the town or state, this does not assure college preparation. For the school approved must be approved not by the colleges, but by the state superintendent of schools, and need not be on the certified list; hence the state does not in all cases provide free preparation for college.

The non-certified high schools may be divided into the following groups:

I. Schools which make no pretense of preparing for college, whose attendance is very small, often ro or $\mathrm{I}_{5}$, whose teaching force is limited to one or two teachers, and which have no laboratory or library facilities. Further, many of these schools have only a twoor three-year course of study. Nearly one-half of the high schools, in some states, belong to the class under consideration.

2. High schools with larger numbers, even reaching ${ }_{50} 0$ pupils, with fair equipment, but with a standard of scholarship so low that they never received certificate-rights with any of the allied colleges. These schools need toning up. Under proper management, and 
especially if supported by the sentiment of the community, they could give a thorough preparation for college.

TABLE III

\begin{tabular}{l|r|r|r|r|r|r}
\hline \hline & Maine & N. H. & Vt. & Mass. & R. I. & Conn. \\
\hline No. high schools................. & I47 & 57 & 64 & 245 & 20 & 77 \\
No. with fewer than 50 pupils........ & 83 & 28 & 38 & 79 & 6 & 36 \\
No. which should have certificate privilege & 64 & 29 & 26 & I66 & I4 & 4I \\
No. with certificate privilege............ & 25 & I7 & 9 & II 2 & I I & I5 \\
\hline
\end{tabular}

3. High schools with limited facilities but excellent ideals. These schools sent (we use the past tense purposely) occasionally to college. The demand for such preparation was not large, but when it came, the pupil was sent to college thoroughly grounded in the traditional classical course. The teaching force was small, the laboratory equipment offered inadequate, if any, advantages, the library consisted, like Lincoln's, of a few well-chosen volumes. Yet along certain lines these schools did an admirable work. For the most part they had certificate privileges with one college, and sought to meet the requirements of that college alone. Under the new régime they were practically cut off, owing either to a lack of equipment or unable to furnish sufficient evidence of ability to give thorough preparation. This latter consists in sending three satisfactorily prepared pupils to one or more of the allied colleges within three years. In fact some of these schools did not ask for the application blank. To be more accurate, we quote from the second annual report of the secretary of the board:

"When the board was organized there were five hundred and thirty-four (534) New England schools on the approved lists of one or more of the ten colleges which had been receiving students by certificate. Of these schools one hundred and forty (I40) have not as yet been heard from; but of this number one hundred were on only one list, twenty-seven more had been approved by only two colleges, and only six (6) had had the approval of more than three."

4. Schools with limited facilities and poor scholarship. These sent only a few graduates to college. Their record was unsatisfactory, their influence demoralizing, and they exasperated the college authorities.

I These statistics apply to both high schools, academies, and private schools. The high schools constitute about two-thirds of the above number. 
5. Schools with ample equipment, but whose pupils made a poor record for scholarship in college. For many of them no sufficient excuse can be offered. Even their officials acknowledge that the certificate privilege was abused, and that the school is justly paying the penalty for indiscretion. They have well-appointed buildings, adequate teaching force, excellent curricula; but the quality of work is poor. Moreover, when a graduate asks for a certificate to college the principal has not the courage to say "No," fearing either unpopularity or loss of position.

There is a disposition on the part of nearly all of these schools to reform, to get back onto the approved list again; but to some the conditions imposed are a source of annoyance. I quote from a representative letter written by a superintendent of schools:

"We are fitting boys for Harvard and Yale, and send a girl to Vassar next fall, and have several others preparing, but the N. E. C. E. Board refused us their O. K. Said we had sent no wellprepared pupils. Formerly, that is six years ago, we had a threeyear high school but changed to four: Latin, Greek, French, three years, German, three years, good laboratories, and mathematics through trigonometry. We have five teachers on high-school work and ninety-five pupils. We send from six to ten to college each year, to Cornell, Vassar, Williams, and Univ. of Vermont."

6. Schools of good standing which object to issuing certificates in any form. The number of these institutions is very small, for the principle of certification is very generally recognized throughout New England.

\section{LOCAL AUTONOMY}

In order to find out how far a lack of professional superintendence is responsible for the poor showing of the above schools, I included the following among a series of questions addressed to the principals of high schools: Is your high school under the charge, directly or indirectly, of a professional superintendent? The one hundred and twenty-five replies may be tabulated as has been done in Table IV. In a very few towns the high-school principal held the dual office of principal and superintendent. Moreover, of the twenty-eight schools never approved, but under a professional superintendent, at least twenty should be on the accredited list, 
judging at least from the size of the school and the teaching force.

\begin{tabular}{|c|c|c|}
\hline \multicolumn{3}{|c|}{ TABLE IV } \\
\hline Formerly Approved & Superintendent & - Number \\
\hline Yes & , Yes & $5 \mathrm{I}$ \\
\hline Yes & No & I2 \\
\hline No & No & 26 \\
\hline No & Yes & 28 \\
\hline \multicolumn{2}{|c|}{ Uncertain of former relations. } & 8 \\
\hline Total & . & 125 \\
\hline
\end{tabular}

At once the question arises, Is the quality of superintendence as efficient as it can be made? There is no gainsaying the fact that a careful examination of the above table might lead one to suppose that professional superintendence did, in many instances, more harm than good. But to one familiar with conditions in New England, it is evident that such is not the case. With few exceptions the superintendents are a hard-working, able, energetic, and conscientious body of men, doing the best that can be done under the restrictions placed upon them and the powers granted to them. As an illustration of the latter, Massachusetts, a few years ago, created the office of district superintendent by allowing two or more towns to unite in employing a superintendent. The only prerogative given by law to this official was the sole right of signing mill cards. For all his authority, for his professional status in the schools, he was indebted to the caprice or good sense of his committee. Thus it is only fair to state in behalf of the superintendents that their work in the schools is restricted and hampered by local sentiment-that all-powerful agency, especially in New England. Further there is no outside authority to act as a court of appeal, to insist upon a definite standard, to conserve the highest welfare of the schools in times of local squabbles. True there are state superintendents of schools, but they have no direct authority in the solution of local problems. Too often the superintendent is obliged to cater to public opinion, to worry over the impending meeting of his school board, to parry the thrusts of malicious opponents. Happy-and rare-is the man who can give his undivided attention to the work of his school, doing what is right with the sure knowledge that his committee will support him and that he will be secure in his official position. Here and there, indeed, 
we find a disposition on the part of the school board to turn the management of the schools over to the superintendent, giving him free rein, and looking to him for results.

I have dealt thus fully with this topic because I am convinced that it is at the root of the evils of our school system. The notion of local autonomy, of town management of affairs, and the repugnance to outside interference, have become so deeply imbedded in the mind of the New Englander, that he is opposed to state control. Consequently New England has some of the very poorest, as well as the very best, schools in the United States. What is required to remedy this is a strongly centralized system of high schools, along the following lines:

I. A high-school inspector, who shall visit the schools, advise principals, teachers, and school boards, and secure a fairly uniform curriculum.

2. Special state aid to the smaller schools; these schools to be sufficiently equipped to prepare for college and technical school.

3. Uniform state examinations for entrance to and promotion in these schools.

4. Professionally trained teachers.

\section{SQUARE DEALING}

The answers to the question: In employing teachers can you rely upon testimonials from college professors? were interesting and shed light upon the present situation. For it has generally been supposed that the high-school principals only were at fault; college officials have repeatedly, and truthfully said the certificate privilege was at times abused; but experience and inquiry lead to the conclusion that the college authorities have been equally lax in giving testimonials to their students. This is evident from the tenor of the replies received. Thirteen answered the above question in the affirmative, fifteen in the negative, twenty-nine had had no experience, and sixty-eight qualified their answers as follows: "In some cases;" "To some extent;" "Not always;" "On questions of scholarship, yes;" "It depends upon who the professors are;" "We do not place much reliance upon them unless we know the professor."

It is refreshing to learn that there has been an awakening of 
conscience in some of the New England colleges, for at least one of them has, I understand, established the unwritten law that testimonials are to be given only to the very best students. If this law should become operative in the other colleges, and if reliable educational bureaus could be established in all the higher institutions of learning, secondary education, and in turn all education, would be benefited thereby.

For, grammar school, high school, and college are inseparably related and mutually react upon one another. The high school is the great source of supply for the colleges, while the colleges furnish the teaching force for the high school. Thus the two are indissolubly bound together. If a high-school principal abuses the certificate privilege, the college suffers, and his own school indirectly; if on the other hand the college professors are too free in giving testimonials to their graduates, they seriously injure the high schools by foisting upon them incapable teachers, and later themselves, when ill-prepared students come from these schools. Granting certificates and writing testimonials should be held as a trust, and carefully guarded as such.

Let me give two extreme instances of flagrant abuse of confidence. A principal certifies to an entire department, no subject of which the boy has studied. This is nothing less than perjury. Again, a college faculty, from president down, gives flattering testimonials to a graduate who is hard of hearing, has an impediment of speech, is near-sighted, and manifestly deficient in educational attainment. Between these extremes there are many gradations, but the penalty for laxness is not the same.

In fact, the whole situation presents a sad picture of the lack of courage on the part of educated men. Too often the college professor is afraid to stand the consequences of telling the whole truth or of refusing to write a testimonial. Frequently a high-school principal will not face the consequences of denying a certificate to the scion of an influential family. The individual college hesitates to cut off from its approved list those schools which do not give adequate preparation; hence the alliance of colleges, for the colleges acting collectively can do what each one would shrink from doing individually. What is demanded is greater courage on the part of school and college officials: the backbone to stand up manfully and do what 
is right, even if it does make enemies among the students, lose votes on the school board, or cause pupils to go to other colleges.

In justice to the Certificate Board I must say that in some instances at least it has respected the reputation for honesty on the part of the principals, and granted the certificate privilege when the previous record of the school did not warrant it, but owing to a change of principal, conditions were changed. I believe that the board is composed of fair-minded men and women, whose honesty of purpose cannot be questioned. Further, the board has advanced the cause of education in that the standard of a large number of schools has been raised, and principals are more careful in issuing certificates.

\section{THE SMALI HIGH SCHOOL}

In comparing the small and the large high school the presumption is usually in favor of the larger institutions. The Certificate Board, however, is in no way influenced by the size of a school; it forms its opinion from the equipment and from the record in college of the graduates of that school. Thus we have an impartial judgment of the merits of the two classes of schools. We naturally expect the larger with its higher-salaried teachers, its better equipment, and more elaborate course of study, to turn out much stronger graduates and overshadow the smaller.

TABLE V

\begin{tabular}{l|r|r|r|r|r|r}
\hline \hline & Maine & N. H. & Vt. & Mass. & R. I. & Conn. \\
\hline No. high schools with certificate privilege & 25 & I 7 & 9 & II 2 & I I & I5 \\
No. of above with fewer than Ioo pupils & I2 & 8 & 3 & 24 & 3 & 8 \\
Per cent. of above with fewer than I00 & & & & & & \\
pupils ........................ & 48 & 47 & 33 & 2 I & 27 & 53 \\
No. towns with 8,00o or more population & II & 9 & 3 & 8 I & I 2 & 20 \\
\hline
\end{tabular}

\section{UNIFORMITY OF TEST}

A prolific source of failure during the freshman year is the lack of any uniformity in testing a student's preparation. So far as the definition of requirements for admission to college is concerned there is, practically, uniformity. And yet, as every secondary teacher knows, this uniformity is only apparent; for there is no uniformity of testing the pupil's preparation. As a matter of fact the individuality of the college is a potent factor in fitting for that college. To illustrate: In history one college emphasizes method; another, original 
research; a third wants the pupil's mind crammed with the facts of history; while still a fourth lays stress upon present events. So also in Latin; one college will go into the minutiae of syntax and etymology; another gives special attention to rapid translation; while a third teaches Latin as literature. Hence I maintain that it would be much fairer to the secondary school, as well as better for the student himself, if the instructor during the first term in college could be less one-sided, and if the colleges could agree upon a uniform test of preparedness.

\section{THE ACCREDITED SCHOOLS}

The following table, taken from the report of the secretary of the Certificate Board for the year 1904-5, furnishes data for comparison between the results of certifying and examining, and also shows in what way the approved schools are meeting the requirements of the colleges:

TABLE VI

\begin{tabular}{|c|c|c|c|c|c|c|}
\hline & English & Latin & Greek & French & German & $\begin{array}{l}\text { Mathe- } \\
\text { matics }\end{array}$ \\
\hline $\begin{array}{r}\text { No. examined............ } \\
\text { No. failed rst term...... } \\
\text { Per cent. failed rst term. } \\
\text { No. certified............. } \\
\text { No. failed rst term...... } \\
\text { Per cent. failed rst term. } \\
\text { Per cent. unsatisfactory in } \\
\text { r } 903-4^{*} . \ldots \ldots \ldots \ldots\end{array}$ & $\begin{array}{l}239 \\
\text { I3 } \\
5 \cdot 5 \\
829 \\
79 \\
9 \cdot 5 \\
20.2\end{array}$ & $\begin{array}{l}184 \\
5 \\
2 \cdot 7 \\
7 \mathrm{II} \\
31 \\
4 \cdot 4 \\
\quad 14\end{array}$ & $\begin{array}{l}71 \\
3 \\
4 \cdot 2 \\
309 \\
6 \\
\quad 1 \cdot 9 \\
\text { II. } 8\end{array}$ & $\begin{array}{l}\text { I55 } \\
\text { 10 } \\
6.5 \\
590 \\
52 \\
8.8 \\
\text { I4 }\end{array}$ & $\begin{array}{r}70 \\
7 \\
\text { 10 } \\
370 \\
29 \\
7.8 \\
13.4\end{array}$ & $\begin{array}{l}273 \\
31 \\
\text { I } 3 \cdot 1 \\
819 \\
\text { I05 } \\
\text { 12.8 } \\
26.4\end{array}$ \\
\hline
\end{tabular}

* Before the inauguration of the present system.

The above statistics afford ample testimony to the thorough manner in which the accredited schools are doing their work, and to the good judgment of the principals who grant certificates. The per cent. of failures is very low, when all conditions are considered. This is especially true in Greek and Latin, while in the other subjects the per cent. is very gratifying. Probably many of the failures in mathematics are due to the recent changes in algebra and geometry. Even here the number is small, relatively. If out of a class of forty entering the high school only five should fail to carry their work successfully, we high-school men would be greatly delighted. Yet why should the college faculties expect a condition to obtain with them that is found nowhere else? If out of a class of fifty in Greek 
only one student fails to carry his work successfully, we are bound to admit that the high schools are giving as thorough a preparation in that subject as any reasonable person could possibly expect.

In conclusion I must express my regret that the present method is not a solution of the vexed problem of articulation between high school and college. We must seek farther for some way by which the colleges may have a direct and constructive influence upon the secondary schools. The suggestions of this plan may be obtained from the systems operative outside of New England. 